\title{
Incidental capture of sea turtles by industrial bottom trawl fishery in the Tropical South-western Atlantic
}

\author{
SUZANA MACHADO GUIMARÃES ${ }^{1}$, DAVI CASTRO TAVARES ${ }^{2}$ AND CASSIANO MONTEIRO-NETO ${ }^{1}$ \\ ${ }^{1}$ Laboratório ECOPESCA - Biologia do Nécton e Ecologia Pesqueira, Departamento de Biologia Marinha, Universidade Federal \\ Fluminense, Niterói, RJ, Cx. Postal 100.644, Brasil, ${ }^{2}$ Laboratório de Ciências Ambientais, Universidade Estadual do Norte \\ Fluminense Darcy Ribeiro, Campos dos Goytacazes, RJ, Brasil
}

\begin{abstract}
The five sea turtle species occurring in Brazilian waters are susceptible to threats, including incidental catches by fisheries. Studies on incidental captures in fishing gears are the main focus of several conservation actions due to high sea turtle fishery mortality worldwide. This study provides the first evaluation of incidental sea turtle catches by industrial bottom trawl fisheries operating in Brazilian waters. Four twin-trawler vessels were monitored between July 2010 and December 2011 by captains who voluntarily completed logbooks. Forty-four turtles were captured during the 1996 tows (8313 fishing hours), resulting in a catch of $5.3 \pm 0.8$ turtles per 1000 h per unit effort. Captured species included the loggerhead turtle (Caretta caretta, 22 individuals), olive ridley turtles (Lepidochelys olivacea, 21 individuals) and one green turtle (Chelonia mydas). Water depth was the only variable that significantly affected sea turtle captures according to Generalized Linear Models. The capture rates reported in this study ranked sixth in relation to other published studies of similar fisheries occurring worldwide. Considering the importance of this region for sea turtles, the increasing evidence of sea turtle mortality and the goals of the National Action Plan for Conservation of Sea Turtles in Brazil, it is essential to identify the main threats towards these animals and propose mitigating solutions to reduce sea turtle mortality induced by fishing activities. This study provides results that may guide future research and goals in meeting sea turtle conservation strategies.
\end{abstract}

Keywords: Trawl fisheries, bycatch, capture per unit effort, Caretta caretta, Lepidochelys olivacea, turtle excluder device

Submitted 3 December 2015; accepted 20 February 2017; first published online 27 March 2017

\section{INTRODUCTION}

Commercial fisheries occur worldwide, affecting target and non-target species, with important impacts on marine ecosystems (Alverson et al., 1994; Gislason et al., 2000). Sea turtles are caught as bycatch (incidental capture of non-target species) in several fisheries. When captured, they are often thrown back into the sea, most of the time injured, drowning or dead (Oravetz, 2000). The impact of bycatches of nontarget populations depends on the life history of the impacted species (Alverson et al., 1994). Due to their long lifespan and late maturation (long juvenile period), sea turtle populations, both adult (reproductive) and juvenile individuals, are highly vulnerable to mortality (Crouse et al., 1987).

All sea turtle species are protected by the Convention on International Trade in Endangered Species of Wild Fauna and Flora (CITES, 2015) and listed as threatened or endangered in the International Union for the Conservation of Nature's Red List (IUCN, 2015). Nevertheless, commercial fisheries continue to threaten sea turtle species due to incidental fishing mortality. Thus, top research and conservation priorities include the identification of areas where sea turtles and

Corresponding author:

S.M. Guimarães

Email: suzanamgr@hotmail.com fisheries overlap, quantification of the impacts on sea turtle populations and the development of solutions to either reduce capture or increase turtle post-capture survival without causing economic losses to fishery activities (National Research Council, 1990; Domingo et al., 2006; FAO, 2009). Since the 1970s, studies evaluating the mortality of sea turtles in trawl fisheries in South Atlantic and Gulf of Mexico have been conducted, and some estimates indicate that more than 10,000 turtles die from bycatch per year (Roithmayr \& Henwood, 1982; Henwood \& Stuntz, 1987; National Research Council, 1990). These estimates provided the basis for the development of the Turtle Excluder Device (TED), an inclined metal grid placed in the trawl to prevent large animals from entering the cod-end. A small opening in the trawl is located either above or below the grid, which allows specimens stopped by the TED to escape, relatively unharmed. Targeted species such as shrimp, however, flow to the back of the cod-end (FAO, 2009).

The size of the continental shelf and habitat variability across several degrees of latitude provide shelter for a high diversity of marine fauna within the Tropical South-western Atlantic (Briggs, 1995). Currently, Brazil is ranked as the 23rd wild marine fish producer (extractive fishing) in the world, contributing to about $7 \%$ of the national Gross Domestic Product (GDP). With 90,559 tons produced in 2010, the south-eastern region of Brazil is ranked third in wild marine fish production within the country (MPA, 
2012). Commercial bottom trawl fishery in south-east Brazil targets shrimps, crabs and an array of bottom-dwelling and demersal fish species. Due to the overcapacity of the fishing fleet, stocks are considered to be overexploited since 2002 (Domingo et al., 2006; Perez \& Pezzutto, 2006). Currently, there are $\sim 1500$ industrial trawlers working off the southeastern Brazilian coast (MPA, 2012).

Five species of sea turtles occur in Brazil: loggerhead (Caretta caretta), leatherback (Dermochelys coriacea), olive ridley (Lepidochelys olivacea), green (Chelonia mydas) and hawksbill (Eretmochelys imbricata) turtles (Peres et al. 2011). Monitoring and reducing bycatch and increasing awareness of the problem in the political arena are three of the main goals of the National Plan for the Conservation of Sea Turtles in Brazil (ICMBio, 2011). Catch per unit efforts (CPUE) of sea turtle bycatch by pelagic longline fisheries have been estimated for the loggerhead turtle (CPUE = $0.8712 / 1000$ hooks) and the leatherback turtle (CPUE $=$ $0.1527 / 1000$ hooks) (Sales et al., 2008). Corresponding CPUE of sea turtles for bottom trawl fishery in Brazil, however, have been unavailable until now. The bycatch of sea turtles in the Brazilian trawl fishery has been previously inferred based on stranding data (Marcovaldi et al., 2006; Reis et al., 2009; Silva et al., 2010). In this context, the present study provides estimates of CPUE sea turtle bycatches by the industrial bottom trawl fishery in the Tropical Southwestern Atlantic area of Brazil, aiming to (1) verify the distribution of the operational area of vessels participating in the study; (2) identify which sea turtles species interact with this fishery; (3) verify which abiotic variables (depth, period of the day, geographic coordinates) may influence sea turtle capture; and (4) compare the CPUE estimates presented herein with others calculated worldwide.

\section{MATERIALS AND METHODS}

\section{Study area}

South-eastern Brazil has $1890 \mathrm{~km}$ of coastline throughout the states of Espírito Santo (ES), Rio de Janeiro (RJ) and São Paulo (SP). These areas are characterized by the tropical humid climate of the Tropical South-western Atlantic (Neto, 2005; IBGE, 2012). The width of the south-eastern continental shelf varies between 50 and $230 \mathrm{~km}$ (Ruffato, 2011). Water masses in the region include the Tropical Water mass (high temperature and salinity), the South Atlantic Central Water mass (low temperature and relatively low salinity) and the Coastal Water mass (high temperature and low salinity) (Martins et al., 2005).

The vessels monitored in this survey belong to Brazil's south-eastern industrial bottom trawl fleet, which lands its catch in the port city of Niterói (inside the Guanabara Bay), in Rio de Janeiro $\left(22^{\circ} 52^{\prime} \mathrm{S} 43^{\circ} 6^{\prime} \mathrm{W}\right)$.

\section{Data collection}

A voluntary logbook programme was implemented between July 2010 and December 2011 to monitor sea turtle bycatch in the trawl fisheries. The captains of three shrimp and one fish trawler collected the data. The fleet owner allowed captains to participate in the data collection for this study. Data were not collected from 1 March to 31 May, due to the annual closure of the fishery (Instrução Normativa IBAMA no 189 de, 2008).

The vessels were about $22 \mathrm{~m}$ in overall length (LOA) and operated two otter trawls coupled with two pairs of wooden doors measuring $\sim 2.3 \mathrm{~m}$ in length and $90 \mathrm{~cm}$ in height. Head-rope length was consistent between all boats, measuring $28.0 \mathrm{~m}$. Trawling speed ranged from 2.0 to $2.6 \mathrm{~nm} \mathrm{~h}^{-1}$. Fishing trips lasted between 10 to 15 days, and vessels typically executed two trips per month. For each trip, between $60-70$ tows each lasting $4.2 \pm 0.9 \mathrm{~h}$ were performed.

All vessel captains recorded the date, time, bottom depth and GPS location (deploying and hauling of trawls) for all tows in both the project and the official logbooks (MMA, 2005). Captains were trained to collect information related to turtle bycatches, namely: turtle species, curved carapace length (CCL) and width (CCW) (Bolten, 200o), and whether the turtle was alive (lively movements), dead/comatose (no breathing, eyes not responding to touch) or drowned (no lively movements but eyes responding to touch). To identify species, the captains used a simplified sea turtle identification key provided with the data collection sheets. To confirm the identified species, the captains photographed the bycaught turtles and project personnel validated this upon return to the docks.

To identify fishing zones of the monitored vessels trawl deployment, GPS coordinates of all recorded tows were plotted. Hauling GPS coordinates were used to plot sea turtle captures, since the capture is only verified when the trawl is hauled back on the boat. Maps were generated using the software Quantum Gis 2.14 package.

\section{Data analysis}

Generalized Linear Models (GLMs) were used to detect which variables influence turtle bycatch by the trawlers monitored in this study (Vernables \& Dichmont, 2004). The number of turtles captured in each tow was included as a response variable under the influence of the following fixed variables: (1) fishing time (hour) at the beginning of each tow (in decimals); (2) water depth (in metres), taken at the end of each tow; (3) tow duration - time (hours) elapsed between the deployment and hauling of each tow; (4) latitude; and (5) longitude taken in decimal degrees at the beginning of each tow.

Models were constructed step-by-step by reducing the full model, which initially included all the fixed variables (Tavares et al., 2015), using the binomial family as the best error distribution, followed by graphical diagnostics (Crawley, 2007; Zuur et al., 2009). The models were selected according to Akaike's Information Criterion (AIC), where the best models produce the lowest AIC scores (Burnham \& Anderson, 2002). As small differences in AIC scores indicate equally supported models, model averaging was performed via the zero method, using a cut-off of 2 AIC (Grueber et al., 2011; Tavares et al., 2015). The importance value for each predictive variable was also calculated as the sum of the Akaike weights along a chain of randomly generated models starting from the full model (Burnham \& Anderson, 2002).

The statistical analyses were performed with the software $\mathrm{R}$ 3.0.1, using the following packages: 'stats' for model fit, 'MuMIn' for model averaging and estimating the importance of variables and 'bbmle' for calculating the AIC values (R Core Team, 2013). In addition, the modelling procedures were 
preceded by a data exploration step, in which outliers, collinearity, and other possible problems were verified, as pointed out by Zuur et al. (2010). Model assumptions were checked by the graphical inspection of the residues. The analysis of collinearity between variables did not exceed a Variance Inflation Factor (VIF) of 2, except for longitude (VIF $=5.83)$ and latitude (VIF = 7.92).

The catch per unit efforts (CPUE) were calculated using fishing hours as the sample unit. The total number of captured turtles was divided by the total number of fishing hours and multiplied by 1000 (turtles per $1000 \mathrm{~h}$ of towing). To compare the calculated estimates with the available literature from the Gulf of Mexico and south-eastern North Atlantic (Henwood \& Stuntz, 1987), prawn fishery of Northern Australia (Poiner \& Harris, 1996), north-eastern Venezuela (Alió et al., 2010), Queensland, Australia (Robins, 1995) and the Pacific side of Costa Rica (Arauz et al., 1997), the efforts per towing hours were based on a single trawl with $30.5 \mathrm{~m}$ head-rope length. All the compared studies used the same standardization method, using the formula according to Henwood \& Stuntz (1987):

$$
E i=n t(H / 30.5 \mathrm{~m})
$$

Where $n=$ number of nets; $t=$ trawling time (h); and $H=$ head-rope length $(\mathrm{m})$.

Turtle CPUE and confidence intervals ( $95 \% \mathrm{CI}$ ) were calculated according to Snedecor \& Cochran (1967) using the formula:

$$
\widehat{R}=\sum_{i=1}^{n} T i / \sum_{i=1}^{n} E i
$$

where $\hat{R}=$ CPUE; $T i=$ number of turtles captured; $E i=$ effort ( $30.5 \mathrm{~m}$ net hour); and $n=$ sample size (number of tows).

Confidence intervals ( $95 \% \mathrm{CI}$ ) were calculated using the formulas below:

$$
\begin{gathered}
\mathrm{CI}=\widehat{R}+1.96 s \hat{R}, \text { and: } \\
s(\widehat{R})=(1 / \bar{E}) \sqrt{\frac{\sum_{i=1}^{n}(T i-\hat{R} E i)^{2}}{n(n-1)}}
\end{gathered}
$$

Where $\widehat{R}=$ estimated average CPUE (turtles/single $30.5 \mathrm{~m}$ trawl per hour); $s(\widehat{R})=$ estimated CPUE; and $\bar{E}=$ the average size of the unit effort in the sample (average tow duration $=4.2 \mathrm{~h}$ ).

\section{RESULTS}

A total of 1996 hauls were recorded during 353 fishing days, totalling 8313 trawling hours. Trawling efforts were distributed between $25^{\circ} \mathrm{S} 46^{\circ} \mathrm{W}$ and $21^{\circ} \mathrm{S} 40^{\circ} \mathrm{W}$, but mostly concentrated off the coast of Rio de Janeiro, due to the proximity of the port to the fishing grounds (Figure 1). Tow duration ranged between 20 and $535 \mathrm{~min}($ mean $=251, \mathrm{SD}=55)$ and tow depths ranged between 24 and $130 \mathrm{~m}$, with most hauls at $\sim 60 \mathrm{~m}($ mean $=59, \mathrm{SD}=22)$. Fishing efforts were slightly higher during the day $(4338 \mathrm{~h})$ when compared with night-time (3975 h).

A total of 44 sea turtles were bycaught by the monitored vessels, resulting in a CPUE $\pm 95 \%$ CI of $5.3 \pm 0.8$ turtles per $1000 \mathrm{~h}$. Fishing efforts were concentrated off the coast of the state of Rio de Janeiro (Figure 2). The captured species were loggerhead $(\mathrm{N}=22)$, olive ridley $(\mathrm{N}=21)$, and green $(\mathrm{N}=1)$ turtles. No mortality was documented, but one drowned turtle was recorded. The curved carapace length (CCC) ranged between 61 and $150 \mathrm{~cm}$ (mean $=83.5$, $\mathrm{SD}=22.3)$ for loggerheads, 56 and $76 \mathrm{~cm}$ (mean $=64.3$, $\mathrm{SD}=4.8$ ) for olive ridleys, and the single green turtle individual measured $38.5 \mathrm{~cm}$. Most sea turtle catches $(\mathrm{N}=34)$ occurred within the $60 \mathrm{~m}$ isobath, which concentrated $63.4 \%$ of the total fishing efforts $(\mathrm{N}=5272 \mathrm{~h})$.

Five GLMs fitted with binomial errors showed similar performance in predicting sea turtle bycatches $(\Delta \mathrm{AIC}<2)$ (Table 1). The small differences in AIC scores prevented the choice of a single best fitting model. According to the model-averaged parameter estimates, sea turtle bycatch by trawl fishery is affected mainly by water depth (Table 2). The model-averaged coefficient indicated that the probability of sea turtle bycatch increases slightly with reduced trawling depth.

To compare the present results with other studies on sea turtle bycatch by trawl fisheries, a standardized effort $(E i)$ of 15,263 towing hours was obtained, with a CPUE $\pm 95 \% \mathrm{CI}$ of $0.0029 \pm 0.004$ turtles per towing hour (Table 3 ).

\section{DISCUSSIDN}

\section{Captured species and influential factors}

The species most captured by bottom trawlers in southeastern Brazil were adult and sub-adult loggerhead and olive ridley turtles. This pattern has been reported in several studies around the world. The loggerhead turtle is the species most affected by bottom trawls (Table 3) (Poiner \& Harris, 1996; Casale et al., 2004; Kuhnert et al., 2011; Domènech et al., 2013), with high catches apparently associated to local species abundance and favourable environmental conditions, such as warm waters and food availability (Robins, 1995; Casale et al., 2004). The loggerhead turtle is the most abundant nester of all five species in Brazil (Marcovaldi \& Chaloupka, 2007) with important nesting areas in northern Rio de Janeiro and Espírito Santo (Marcovaldi \& Marcovaldi, 1999; Lima et al., 2012), which may explain the high bycatch rates of adult individuals in bottom trawl fishery.

High capture rates of olive ridleys have been associated with local abundance and proximity to nesting sites (Casale et al., 2007; Murray, 2008). Sales et al. (2008) recorded the capture of 71 olive ridleys in longlines between latitudes $10^{\circ} \mathrm{N}$ and $10^{\circ} \mathrm{S}$, where nesting occurs. However, nesting sites for this species in Brazil are located in the north-eastern region, far from the present study area. Thus, captures between $35^{\circ} \mathrm{S}$ and $15^{\circ} \mathrm{S}$ are not linked to nesting behaviour, but rather with feeding behaviour. Studies based on carcasses found washed ashore and telemetry of live individuals in south-eastern Brazil show that olive ridleys nesting in northeast Brazil move southward to Rio de Janeiro in order to feed. Feeding and resting areas for this species seem to 


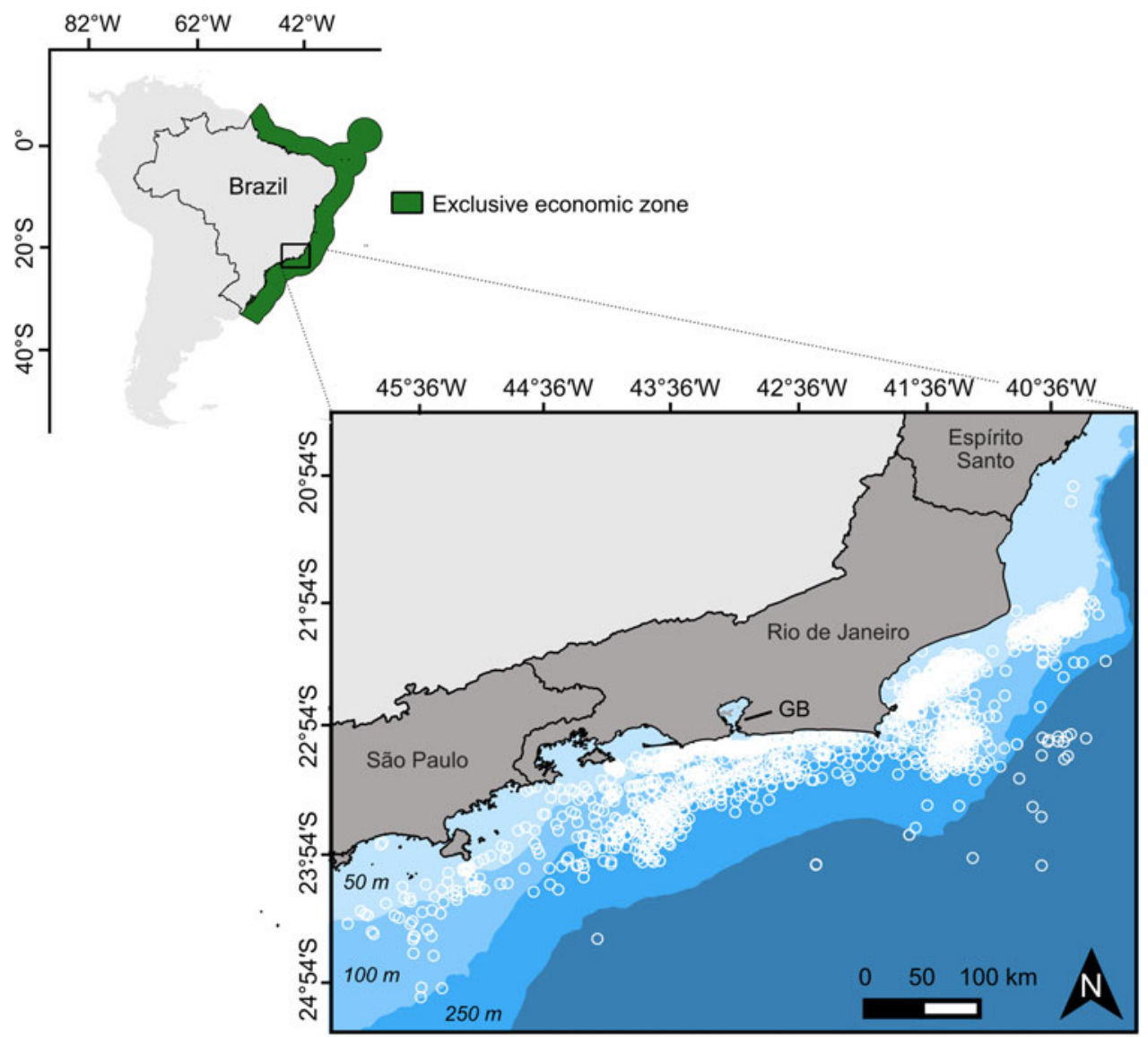

Fig. 1. Geographic distribution of hauls reported during the survey along the states of São Paulo, Rio de Janeiro and Espírito Santo. The inset shows South America, Brazil and the Brazilian south-eastern region. GB, Guanabara Bay.

overlap with the area fished by trawlers. Furthermore, this region may be an important foraging ground for olive ridleys (Lemke et al., 2003; Reis et al., 2009) and the results presented herein provide additional evidence to support this hypothesis.

Water depth was the most significant variable associated with sea turtle bycatch. Sea turtles show a wide range in diving depth and duration, but most species spend more time in shallow waters (Lutcavage \& Lutz, 1996). Olive

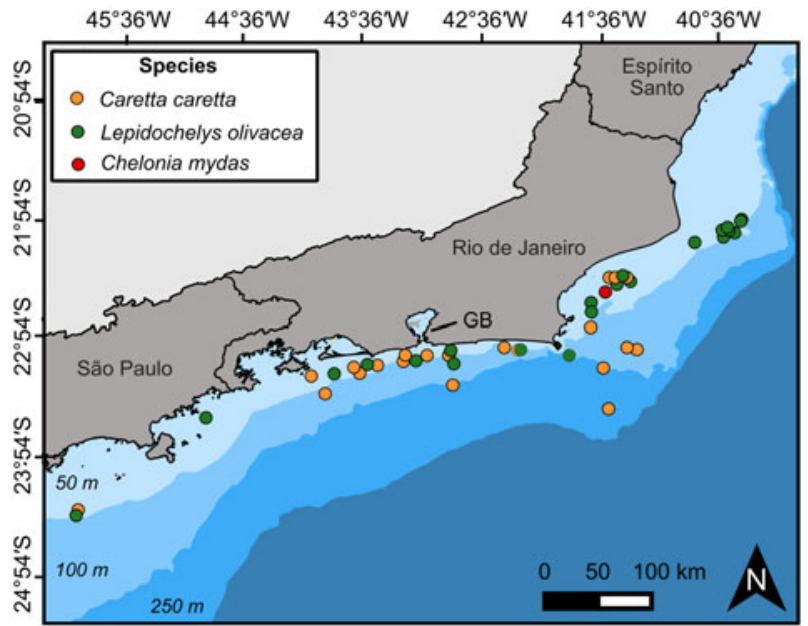

Fig. 2. Geographic and depth distribution of sea turtle catches, by species, off the south-eastern Brazilian coast. GB, Guanabara Bay. ridleys usually perform longer and deeper dives than loggerheads, but both species spend most of their time in waters less than $60 \mathrm{~m}$ in depth (Polovina et al., 2003; Swimmer et al., 2006). Diving depth is also associated with water temperature and activity level. Deeper dives usually occur during resting periods in cold waters, with reduced activity (Hochscheid et al., 2007; Murray, 2008). The warm surface Tropical Water mass (TW) and the cold sub-surface South Atlantic Central Water mass (SACW) are the most important water masses influencing the continental shelf in southeastern Brazil. During the spring-summer, prevailing northeasterly winds generate a coastal upwelling of the SACW, centred at $42^{\circ} \mathrm{W}$, where the continental shelf is narrow, providing an important sea turtle feeding ground which may lead to bycatches during foraging or resting periods (Polovina et al., 2004; Amorocho \& Reina, 2007).

Table 1. Ranking of the best fitted Binomial Generalized Linear Models for sea turtle incidental captures by the trawl fishery as function of predictive variables off the coast of Rio de Janeiro, Brazil.

\begin{tabular}{lll}
\hline Top ranked models & $\Delta$ AIC & $\boldsymbol{w}_{\boldsymbol{i}}$ \\
\hline Sea turtle capture $=$ Water depth & 0 & 0.26 \\
Sea turtle capture $=$ Water depth + Latitude & 0.7 & 0.18 \\
Sea turtle capture $=$ Water depth + Longitude & 1.2 & 0.14 \\
Sea turtle capture $=$ Water depth + Fishery duration & 1.5 & 0.12 \\
Sea turtle capture $=$ Water depth + Period & 1.6 & 0.12
\end{tabular}

$\Delta$ AIC, Akaike's information criterion; $w_{i}$, Akaike weights. 
Table 2. Statistics for the Binomial Generalized Linear Model for sea turtle incidental captures by the trawl fishery as functions of predictive variables off the coast of Rio de Janeiro, Brazil. Water depth was the only significant variable $\left(^{*}\right)$.

\begin{tabular}{|c|c|c|c|c|c|c|}
\hline Model-averaged coefficients & Estimate & CI lower & CI upper & $Z$ value & $P$ value & Importance \\
\hline Water depth & -0.02 & -0.05 & -0.007 & 2.63 & $0.009^{*}$ & 1 \\
\hline Latitude & -0.09 & -0.96 & 0.25 & 0.41 & 0.68 & 0.34 \\
\hline Longitude & -0.02 & -0.34 & 0.12 & 0.32 & 0.75 & 0.34 \\
\hline Fishery duration & 0.02 & -0.21 & 0.47 & 0.26 & 0.8 & 0.27 \\
\hline
\end{tabular}

CI, confidence interval; $\mathrm{Z}$, Wald $\mathrm{Z}$ test output; $P$, statistical significance.

Table 3. Standardized CPUE (turtles per towing hour) obtained in this study compared with other sea turtle catches in trawl fisheries studies conducted worldwide. Data are presented from highest to lowest CPUE.

\begin{tabular}{|c|c|c|c|c|}
\hline Region & CPUE & $\begin{array}{l}\text { Average trawl } \\
\text { duration (min) }\end{array}$ & $\begin{array}{l}\text { Species captured in } \\
\text { decreasing order }\end{array}$ & Study \\
\hline Costa Rica (Pacific Ocean) & 0.1019 & 270 & LO, CM, EM & Arauz et al. (1997) \\
\hline EUA (SE) & 0.0487 & 150 & $\mathrm{CC}, \mathrm{LK}, \mathrm{CM}$ & Henwood \& Stuntz (1987) \\
\hline Australia - Gulf of Carpentaria & 0.0113 & 180 & $\mathrm{ND}, \mathrm{CC}, \mathrm{LO}, \mathrm{CM}$ & Poiner \& Harris (1996) \\
\hline Australia - Queensland (NE) & 0.0057 & $<90 /<155$ & $\mathrm{CC}, \mathrm{CM}, \mathrm{ND}, \mathrm{EI}$ & Robins (1995) \\
\hline Gulf of México $(\mathrm{N})$ & 0.0031 & & $\mathrm{CC}, \mathrm{LK}, \mathrm{CM}$ & Henwood \& Stuntz (1987) \\
\hline Brazil (SE) & 0.0029 & 250 & $\mathrm{CC}, \mathrm{LO}, \mathrm{CM}$ & Present study \\
\hline Venezuela (NE) & 0.0011 & 180 & EI, CM, CC, DC & Alió et al. (2010) \\
\hline
\end{tabular}

\section{Impact of trawl fisheries on sea turtles}

The present study indicated that the CPUE calculated in this study was the sixth highest when compared with similar studies conducted worldwide. The fact that the estimates herein are within the range recorded by other researchers who used on-board observers (Henwood \& Stuntz, 1987; Arauz et al., 1997; Alió et al., 2010) suggests that voluntary data collection by boat captains may be an efficient way of providing estimates of sea turtle catches and CPUE.

Four of six studies used for comparative analyses indicate that loggerhead and olive ridley turtles are the main bycaught species. Differences in CPUE between the species may be due to the differences in the distribution and population size of bycaught species. For instance, the flatback turtle (Natator depressus), endemic to Australian waters, is the most common sea turtle species bycaught in bottom trawls in that area, with loggerheads being the second most bycaught species (Poiner \& Harris, 1996). Green turtles are often captured in shallow coastal waters (Robins, 1995; Arauz et al., 1997; Alió et al., 2010) where this species is commonly found (Marquez, 1990).

The present study demonstrated that trained vessel captains from industrial trawlers operating in the Tropical South-western Atlantic could provide data on sea turtle bycatches. Trust was built between the research team and collaborative captains in order to obtain reliable estimates. However, underreporting could still have occurred, resulting in underestimates of sea turtle CPUEs, as captains may have been reticent to report catches due to possible penalties foreseen in the Brazilian legislation. Despite the criticism of using logbook information data (FAO, 2009), this information may be relevant when better information is lacking (Robins, 1995; Poiner \& Harris, 1996). Developing collaborative fisheries research is essential to obtain reliable data, to evaluate the demographic effects of bycatches and to achieve progress in bycatch mitigation (Soykan et al., 2008; Sales et al., 2010). Thus, this initiative may be a good starting point leading to additional research programmes, especially since research funds are limited.

Using TEDs is currently mandatory in Brazil, but the industry often neglects their use in trawls, since boat captains claim that TEDs reduce the catch volume of target species. To date, no complete comparison experiments have been conducted to determine TED efficiency in Brazilian waters. In addition, captains indicate that little information, instructions or training activities on proper TED use are available, which inhibits the use of this equipment by crews (Tamar-Ibama, 2007). Since TED use is currently not widespread, it could be worthwhile to teach captains best handling practices for turtles when captured, such as learning turtle reanimation techniques which could aid in reducing turtle mortality in this fishery (FAO, 2009). The information presented herein indicates that the bycatch of sea turtles by the bottom trawl fisheries within the Brazilian Exclusive Economic Zone (EEZ) waters in the Tropical South-western Atlantic occurs at levels that may affect sea turtle conservation efforts. Systematic monitoring of bottom trawl fisheries is, thus, required to further understand bycatch levels and to provide additional data for improved evaluations of sea turtle populations, which will in turn benefit the conservation of these animals.

\section{ACKNDWLEDGEMENTS}

We thank all boat captains and the owner of the company for their voluntary participation in this study. Without the captains' goodwill, this study would not have been possible.

\section{FINANCIAL SUPPORT}

S.M.G. and C.M.N. held fellowships from Conselho Nacional de Desenvolvimento Científico e Tecnológico - CNPq during this study. D.C.T. is supported by Coordenação de Aperfeiçoamento de Pessoal de Nível Superior-CAPES. 


\section{REFERENCES}

Alió J.J., Marcano L.A. and Altuve D.E. (2010) Incidental capture and mortality of sea turtles in the industrial shrimp trawling fishery of northeastern Venezuela. Ciencias Marinas 36, 161-178.

Alverson D.L., Freeberg M.H., Pope J.G. and Murawski S.A. (1994) A global assessment of fisheries bycatch and discards. FAO Fisheries Technical Paper, no. 339, 233 pp.

Amorocho D.F. and Reina R.D. (2007) Feeding ecology of the East Pacific green sea turtle Chelonia mydas agassizii at Gorgona National Park, Colombia. Endangered Species Research 3, 43-51.

Arauz R.M., Vargas R., Naranjo I. and Gamboa C. (1997) Analysis of the incidental capture and mortality of sea turtles in the shrimp fleet of Pacific Costa Rica. In Witzell W.N. (ed.) Proceedings of the Seventeenth Annual Symposium on Sea Turtle, Orlando, Florida, 4-8 March 1997. NOAA Tech. Memo. NMFS-SEFSC-415, pp. 1-5.

Bolten A.B. (2000) Técnicas parar la medición de tortugas marinas. In Eckert K.A., Bjorndal K.A., Abreu-Grobois F.A. and Donnelly M. (eds) Técnicas de Investigación y Manejo para la Conservación de las Tortugas Marinas. Washington, DC: UICN/CSE. Grupo de Especialistas en Tortugas Marinas Publicación no. 4, pp. 126-131.

Briggs J.C. (1995) Global biogeography. Developments in paleontology and stratigraphy, Volume 14. Amsterdam: Elsevier.

Burnham K.P. and Anderson D.R. (2002) Model selection and multimodel inference. New York, NY: Springer.

Casale P., Cattarino L., Freggi D., Rocco M. and Argano R. (2007) Incidental catch of marine turtles by Italian trawlers and longlines in the central Mediterranean. Aquatic Conservation: Marine and Freshwater Ecosystems 17, 686-701.

Casale P., Laurent L. and De Metrio G. (2004) Incidental capture of marine turtles by the Italian trawl fishery in the north Adriatic Sea Biological Conservation 119, 287-295.

CITES (2015) Convention on International Trade in Endangered Species of Wild Fauna and Flora. https://cites.org/eng/app/appendices.php.

Crawley M.J. (2007) The R book. 2nd edition. Chichester: John Wiley \& Sons.

Crouse D.T., Crowder L.B. and Caswell H. (1987) A stage-based population model for loggerhead sea turtles and implications for conservation. Ecology 68, 1412-1423.

Domènech F., Bitón S., Merchán M., Revuelta O., Vélez-Rubio G. and Tomás J. (2013) Incidental catch of the loggerhead turtle (Caretta caretta) by bottom trawling. In the Valencian Community (East Spain). In Belskis L. (ed.) Proceedings of the Thirty-Third Annual Symposium on Sea Turtle, Baltimore, Maryland, 5-8 March 2013. NOAA Technical Memorandum NOAA NMFS-SEFSC-645, pp. 94-95.

Domingo A., Bugoni L., Prosdocimi L., Miller P., Laporta M., Monteiro D.S., Estrades A. and Albareda D. (2006) The impact generated by fisheries on sea turtles in the Southwestern Atlantic. WWF Progama Marino para Latinoamérica y el Caribe, San José, Costa Rica, 70 pp.

FAO (2009) Guidelines to reduce sea turtle mortality in fishing operations. Rome: FAO Fisheries Department, 139 pp.

Gislason H., Sinclair M., Sainsbury K. and O'Boyle R. (2000) Symposium overview: incorporating ecosystem objectives within fisheries management. ICES Journal of Marine Science 57, 468-475.

Grueber C.E., Nakagawa S., Laws R.J. and Jamison I.G. (2011) Multimodel inference in ecology and evolution: challenges and solutions. Journal of Evolutionary Biology 24, 699-711.

Henwood T.A. and Stuntz W.E. (1987) Analysis of sea turtle capture and mortalities during commercial shrimp trawling. Fisheries Bulletin 85, 813-817.
Hochscheid S., McMahon C.R., Bradshaw C.J.A., Maffucci F., Bentivegna F. and Hays G.C. (2007) Allometric scaling of lung volume and its consequences for marine turtle diving performance. Comparative Biochemistry and Physiology A - Molecular and Integrative Physiology 148, 360-367.

IBGE (2012) Mapa de clima do Brasil. Instituto Brasileiro de Geografia e Estatística. http://geoftp.ibge.gov.br/mapas_tematicos/mapas_murais/ clima.pdf.

ICMBio (2011) Plano de ação nacional para a conservação das tartarugas marinhas. Marcovaldi M.A.A.G. and Santos A.S. (eds). Brasília: Instituto Chico Mendes de Conservação da Biodiversidade, 120 pp.

Instrução Normativa IBAMA no 189 de (2008) Prohibits the exercise of trawling with motorized traction for catch pink shrimp (Farfantepenaeus paulensis, F. brasiliensis and F. subtilis), Atlantic seabob shrimp (Xiphopenaeus kroyeri), white shrimp (Litopenaeus schmitti), santana or red (Pleoticus muelleri) and Argentine stiletto shrimp (Artemesia longinaris) annually in the marine area between the parallel $21^{\circ} 18^{\prime} \mathrm{O} 4, \mathrm{Oo}^{\prime \prime} \mathrm{S}$ (the border between the states of Espírito Santo and Rio de Janeiro) and $33^{\circ} 40^{\prime} 33, \mathrm{oo}^{\prime \prime} \mathrm{S}$ (Foz do Chuí Stream , state of Rio Grande do Sul), from March 1 to May 31. [English version]

IUCN (2015) Red list of threatened animals. Gland: IUCN. http://www. redlist.org.

Kuhnert P.M., Griffihs S. and Brewer D. (2011) Assessing population changes in bycatch species using fishery-dependent catch rate data. Fisheries Research 108, 15-21.

Lemke D., Frazier J., Thomé J.C., Almeida A.P. and Juarez S. (2003) Satellite telemetry of loggerheads in Brazil. In Pilcher N.J. (ed.) Proceedings of the Twenty-third Annual Symposium on Sea Turtle Biology and Conservation, 17-21 March 2003. Kuala Lumpur, Malaysia, pp. 230-233.

Lima E.P., Wanderline J., Almeida D.T., Lopez G. and Goldberg D.W. (2012) Nesting ecology and conservation of loggerhead sea turtle (Caretta caretta) in Rio de Janeiro, Brazil. Chelonian Conservation and Biology 11, 294-254.

Lutcavage M.E. and Lutz P.L. (1996) Dive physiology. In Lutz P.L. and Musick J.A. (eds) The biology of sea turtles. Boca Raton, FL: CRC Press, pp. 277-296.

Marcovaldi M.A. and Chaloupka M. (2007) Conservation status of the loggerhead sea turtle in Brazil: an encouraging outlook. Endangered Species Research 3, 133-143.

Marcovaldi M.A. and Marcovaldi G. (1999) Marine turtles of Brazil: the history and structure of Projeto TAMAR-IBAMA. Biological Conservation 91, 35-41.

Marcovaldi M.A., Sales G., Thomé J.C.A., Silva A.C.C.D., Gallo B.M.G., Lima E.H.S.M., Lima E.P. and Bellini C. (2006) Sea turtles and fishery interactions in Brazil: identifying and mitigating potential conflicts. Marine Turtle News Letter 112, 4-8.

Marquez M.R. (1990) FAO species catalogue: Sea turtles of the world. An annotated and illustrated catalogue of sea turtle species known to date. No. 125, Volume 11. Rome: FAO Fisheries Synopsis.

Martins A.S., Olavo G. and Costa P.A.S. (2005) Recursos demersais capturados com espinhel de fundo no talude superior da região entre Salvador (BA) e o Cabo de São Tomé (RJ). In Costa P.A.S., Martins A.S. and Olavo G. (eds) Pesca e potenciais de exploração de recursos vivos na região central da Zona Econômica Exclusiva Brasileira. Rio de Janeiro: Museu Nacional 13, pp. 109-128.

MMA (Ministério do Meio Ambiente) (2005) Instrução Normativa Interministerial No 26, de 19 de julho de 2005. Estabelecer critérios e procedimentos para preenchimento e entrega de Mapas de Bordo das embarcações nacionais ou estrangeiras arrendadas, devidamente permissionadas, que operam em águas sob jurisdição brasileira, em alto mar ou em águas incluídas em acordos internacionais dos quais 
o Brasil é signatário. Ministério do Meio Ambiente - MMA e Secretaria Especial da Pesca e Aquicultura - SEAP.

MPA (Ministério da Pesca e Aquicultura) (2012) Boletim estatístico da pesca e aquicultura - Brasil 2010. Brasília, DF: Ministério da Pesca e Aquicultura.

Murray K.T. (2008) Estimated average annual bycatch of loggerhead sea turtles (Caretta caretta) in US mid-Atlantic bottom otter trawl gear 1996-2004. 2nd edition. La Jolla, CA: US Department of Commerce, NOAA Northeast Fisheries Science Center. Ref. Doc. 08-20, 32 pp.

National Research Council (1990) Decline of the sea turtles: causes and prevention. Committee on Sea Turtle Conservation. Washington, DC: National Academy Press.

Neto J.L.S. (2005) Decálogo da Climatologia do Sudeste Brasileiro. Revista Brasileira de Climatologia 1, 43-60.

Oravetz C.A. (2000) Reducción de la captura incidental en las pesquerías. In Eckert K.L., Bjorndal K.A., Abreu-Grobois F.A. and Donnelly M. (eds) Técnicas de Investigación y Manejo para la Conservación de las Tortugas Marinas. Washington, DC: UICN/CSE. Grupo de Especialistas en Tortugas Marinas Publicación, no. 4, pp. 217-222.

Peres M.B., Magris R.A. and Ribeiro K.T. (2011) Avaliação do estado de conservação das tartarugas marinhas. Biodiversidade Brasileira 1, 1 - 2 .

Perez J.A.A. and Pezzuto P.R. (2006) A pesca de arrasto de talude do Sudeste e Sul do Brasil: tendências da frota nacional entre 2001 e 2003. Boletim do Instituto de Pesca 32, 127-150.

Poiner I.R. and Harris A.N.M. (1996) Incidental capture, direct mortality and delayed mortality of sea turtles in Australia's Northern Prawn Fishery. Marine Biology 125, 813-825.

Polovina J.J., Balazs G.H., Howell E.A., Parker D.M., Seki M.P. and Dutton P.H. (2004) Forage and migration habitat of loggerhead (Caretta caretta) and olive ridley (Lepidochelys olivacea) sea turtles in the central North Pacific Ocean. Fisheries Oceanography 1, 36-51.

Polovina J.J., Howell E. and Balaz G.H. (2003) Dive-depth distribution of loggerhead (Caretta caretta) and olive ridley (Lepidochelys olivacea) sea turtles in the central North Pacific: might deep longline sets catch fewer turtles? Fisheries Bulletin 101, 189-193.

R Core Team (2013) A language and environment for statistical computing. Vienna: R Foundation for Statistical Computing.

Reis E.C., Silveira V.V.B. and Siciliano S. (2009) Records of stranded sea turtles on the coast of Rio de Janeiro State, Brazil. Marine Biodiversity Records 2, 1-4.

Robins J.B. (1995) Estimated catch and mortality of sea turtles from the east coast otter trawl fishery of Queensland, Australia. Biological Conservation 74, 157-167.

Roithmayr C. and Henwood T. (1982) Incidental catch and mortality report. Final Report to Southeast Fisheries Center. Miami, FL: National Marine Fisheries Service, NOAA, 20 pp.

Ruffato D.G. (2011) Circulação na plataforma continental interna e média do estado de São Paulo durante o verão: estudos numéricos. Master thesis. Universidade de São Paulo, São Paulo, Brazil.
Sales G., Giffoni B.B. and Barata P.C.R. (2008) Incidental catch of sea turtles by the Brazilian pelagic longline fishery. Journal of the Marine Biological Association of the United Kingdom 88, 853-864.

Sales G., Giffoni B.B., Fiedler F.N., Azevedo V., Kotas J.E., Swimmer Y. and Bugoni L. (2010) Circle hook effectiveness for the mitigation of sea turtle bycatch and capture of target species in a Brazilian pelagic longline fishery. Aquatic Conservation Marine and Freshwater Ecosystems 20, 428-436.

Silva A.C.C.D., Castilhos J.C., Santos E.A.P., Brondízio L.S. and Bugoni L. (2010) Efforts to reduce sea turtle bycatch in the shrimp fishery in Northeastern Brazil through a co-management process. Ocean and Coastal Management 53, 570-576.

Snedecor G.W. and Cochran W.G. (1967) Statistical methods. 6th edition. Ames, IO: Iowa State University Press.

Soykan C.U., Moore J.E., Zydelis R., Crowder L.B., Safina C. and Lewison R.L. (2008) Why study bycatch? An introduction to the theme section on fisheries bycatch. Endangered Species Research 5, $91-102$.

Swimmer Y., Arauz R., McCracken M., Naughton L.M., Ballestero J., Musyl M., Bigelow K. and Brill R. (2006) Diving behavior and delayed mortality of olive ridley sea turtles Lepidochelys olivacea after their release from longline fishing gear. Marine Ecology Progress Series 323, 253-261.

Tamar-Ibama (2007) Estado da arte sobre a interação das tartarugas marinhas com pesca de arrasto de camarão ao longo da costa brasileira e sobre o uso do dispositivo de escape de tartarugas - TED. Brasília: Ministério do Meio Ambiente, IBAMA, 6o pp.

Tavares D.C., Guadagnin D.L., Moura J.F., Siciliano S. and Merico A. (2015) Environmental and anthropogenic factors structuring waterbird habitats of tropical coastal lagoons: implications for management. Biological Conservation 186, 12-21.

Vernables W.N. and Dichmont C.M. (2004) GLMs, GAMs and GLMMs: an overview of theory for applications in fisheries research. Fisheries Research 70, 319-337.

Zuur A.F., Ieno E.N. and Elphick C.S. (2010) A protocol for data exploration to avoid common statistical problems. Methods in Ecology and Evolution 1, 3-14.

and

Zuur A.F., Ieno E.N., Walker N.J., Saveliev A.A. and Smith G.M. (2009) Mixed effects models and extensions in ecology with R. New York, NY: Springer.

Correspondence should be addressed to:

S.M. Guimarães

Laboratório ECOPESCA - Biologia do Nécton e Ecologia Pesqueira, Departamento de Biologia Marinha,

Universidade Federal Fluminense,

Niterói, RJ, Cx. Postal 100.644, Brasil

email: suzanamgr@hotmail.com 